\title{
Current situation and prospects for the horse meat market in Poland and the world
}

\author{
EWA JASTRZĘBSKA, TOMASZ DASZKIEWICZ*, \\ ALEKSANDRA GÓRECKA-BRUZDA**, DINA FELIŚ

\begin{abstract}
Department of Horse Breeding and Riding, Faculty of Animal Bioengineering, University of Warmia and Mazury, Prawocheńskiego 2, 10-719 Olsztyn, Poland

*Department of Commodity Science and Processing of Animal Raw Materials, Faculty of Animal Bioengineering, University of Warmia and Mazury, Oczapowskiego 5, 10-719 Olsztyn, Poland

**Institute of Genetics and Animal Breeding of the Polish Academy of Sciences in Jastrzębiec, Postępu 36A, 05-552 Magdalenka, Poland
\end{abstract}

\section{Jastrzębska E., Daszkiewicz T., Górecka-Bruzda A., Feliś D. \\ Current situation and prospects for the horse meat market in Poland and the world}

Summary

Humans have developed strong emotional connections with horses throughout the centuries, and horses continue to occupy a special place among other livestock animals. For this reason, horses are reared industrially for slaughter only in some countries. Horse meat is characterized by a high content of protein of high biological value and low levels of fat with a desirable fatty acid profile. Aged horse meat has a long shelf life, and it is an attractive food and raw material for further processing. The high demand for high quality raw horse meat creates new opportunities for breeders, and it could become an alternative or supplementary source of income for traditional livestock farms.

Keywords: horse meat, meat quality, production

The meat of wild horses was consumed by humans as early as the Paleolithic Era. Equine bones discovered in a 9-meter-thick layer of animal skeletons in Solutré, France, and 300,000 horse bones excavated in Botai, Kazakhstan, indicate that horses became a hunted species around 3500-3100 BC (9). Herds of wild horses were a source of milk, meat and hides for humans. Vikings ate horses and sacrificed them to gods, and similar rituals were performed by Icelanders and other Germanic and Celtic peoples. Archeological discoveries suggest that the consumption of horse meat was significantly influenced by cultural and religious factors $(4,8,21)$.

In Europe, the consumption and ritual sacrifice of horses was banned in the $8^{\text {th }}$ century upon the introduction of Christianity. Horse meat returned to European tables only in the early $19^{\text {th }}$ century, when the numerous wars waged on the European continent had led to a meat shortage. Denmark was the first country to legalize the sale of horse meat in 1841, as did the German state of Württemberg; Bavaria followed in 1842, and Prussia in 1843 (12). Several years later, horse meat was widely available in other European states (Norway, Sweden, Austria, Switzerland). In Berlin, horse slaugh- terhouses were established already in the 1840s, and the first abattoirs in Prussian-controlled Polish cities (Wrocław, Poznań and Gdańsk) opened in the 1870s. In the first years of the $20^{\text {th }}$ century (1908), 140,000 horses were slaughtered in Prussia (8).

Today, horses are used mainly for sports, recreation, agriculture and agritourism (32). In some countries, horses are raised for meat which is a popular food and culinary product (4).

The aim of this study was to analyze the current situation on the Polish and global markets of horse meat and to describe the prospects for the development of this sector.

\section{Quality attributes of horse meat}

Horse meat is characterized by sensory attributes and nutritional value equally desirable as those of other types of meat $(25,26,32)$. Horse meat is a source of valuable nutrients, it is lean, low in calories and high in protein, which has a high biological value and a desirable amino acid profile. The total protein content of horse meat is estimated at $20-21 \%$, but according to Hertrampf (8) and Zin et al. (35), it can range from $17.6 \%$ in adult horses to $22.4 \%$ in foals. Horse meat 
is a rich source of essential amino acids, mostly lysine, leucine and arginine, as well as non-essential amino acids, mainly glutamic acid, aspartic acid and alanine. Horse meat is least abundant in thyrosine, serine and proline (23). The presence of poorer-quality connective tissue proteins de-

Tab. 1. Total pool and ratios of fatty acids in horse meat (M. longissimus dorsi)

\begin{tabular}{|l|c|c|c|}
\hline \multicolumn{1}{|c|}{ Total pool and ratios of fatty acids } & $\begin{array}{c}|c| \\
\text { Badiani et al. (2) } \\
\text { (\% of total fatty acids) }\end{array}$ & $\begin{array}{c}\text { Reference } \\
\text { Tonial et al. (32) } \\
\text { \% of total fatty acids) }\end{array}$ & $\begin{array}{c}\text { Franco and Lorenzo (7) } \\
\text { (g/100 g IMF) }\end{array}$ \\
\hline Saturated fatty acids (SFA) & $34.77 \pm 0.38$ & $36.8 \pm 0.80$ & $35.88-35.79$ \\
\hline Monounsaturated fatty acids (MUFA) & $46.53 \pm 0.61$ & $27.4 \pm 0.66$ & $31.49-40.97$ \\
\hline Polyunsaturated fatty acids (PUFA) & $18.64 \pm 0.73$ & $35.8 \pm 1.13$ & $23.23-32.61$ \\
\hline n-6 & - & $34.9 \pm 1.13$ & $15.67-19.37$ \\
n-3 & - & $0.86 \pm 0.02$ & $7.27-13.01$ \\
n-6/n-3 PUFA ratio & 3.61 & $40.6 \pm 1.16$ & $1.48-2.15$ \\
\hline PUFA/SFA ratio & 0.54 & $0.97 \pm 0.21$ & $0.64-0.90$ \\
\hline
\end{tabular}
creases the biological value of protein. Collagen accounts for $3.5 \%$ of total proteins in horse meat, and its content varies between meat quality classes and primal cuts in the carcass. According to Korzeniowski et al. (18), collagen content is lowest in the leg and highest in the neck.

Horse meat is lean and generally contains $0.5 \%$ to $3 \%$ of fat (6). Fat content can vary significantly, from $0.15 \%$ to $16.5 \%$, subject to breed, type, age, diet, season, conformation class and primal cut in the carcass $(17,23,41)$. According to Dobranić et al. (6), the energy value of medium-fat horse meat is $472 \mathrm{~kJ}$ per

Tab. 2. Selected vitamin content of raw horse meat (per $100 \mathrm{~g}$ )

\begin{tabular}{|c|c|c|c|}
\hline \multirow[b]{2}{*}{ Vitamin } & \multicolumn{3}{|c|}{ Reference } \\
\hline & Badiani et al. (2) & Lee et al. (20) & $\begin{array}{l}\text { Lombardi-Boccia } \\
\text { et al. (22) }\end{array}$ \\
\hline Thiamin $\left(B_{1}\right), \mathrm{mg}$ & $0.043 \pm 0.005$ & $0.20 \pm 0.02$ & $0.18 \pm 0.08$ \\
\hline Riboflavin $\left(\mathrm{B}_{2}\right)$, mg & $0.18 \pm 0.004$ & $0.21 \pm 0.04$ & $0.20 \pm 0.01$ \\
\hline Niacin $\left(\mathbf{B}_{3}\right), \mathrm{mg}$ & $5.54 \pm 0.15$ & $1.65 \pm 0.13$ & $7.3 \pm 0.26$ \\
\hline Pyridoxine $\left(\mathrm{B}_{6}\right)$, mg & $0.64 \pm 0.07$ & - & - \\
\hline Cobalamin $\left(B_{12}\right), \mu g$ & $2.08 \pm 0.21$ & - & - \\
\hline Retinol (A), $\mu \mathrm{g}$ & - & $30.0 \pm 8.0$ & - \\
\hline
\end{tabular}
$100 \mathrm{~g}$, which is significantly lower in comparison with pork $(1900 \mathrm{~kJ})$, beef and veal $(760 \mathrm{~kJ})$. Fatty tissue is deposited at specific locations in the half carcass of the horse and can be easily separated from primal cuts (2). Znamirowska et al. (41) reported that subcutaneous and intermuscular fat account for most $(56 \%)$ of the body's adipose tissue, followed by perirenal fat (35\%) and neck crest fat $(9 \%)$.

Horse fat is softer than pork fat, and it resembles poultry fat. For this reason, horse fat is referred to as lard, rather than tallow (8). It is a rich source of unsaturated fatty acids (Tab. 1) with a desirable n-6/n-3 PUFA ratio $(5,7,20,32)$.

Unlike the meat of other animals, horse meat is abundant in sugar, mainly due to high levels of glycogen stored in muscles. The glycogen content of the longissimus muscle is estimated at $60-100 \mathrm{mmol} / \mathrm{kg}$ of tissue in cattle (10) and $85 \mathrm{mmol} / \mathrm{kg}$ in pigs (28), whereas in horses, it is generally 1.5 -fold higher than in cattle (10). High glycogen levels in horse muscles are responsible for the characteristic sweet taste of horse meat (40).

The meat of different animals is generally characterized by similar content of minerals, and differences are observed mostly in the concentrations of individual nutrients. Korzeniowski et al. (18) noted high levels of phosphorus $(453.73 \mathrm{mg} / 100 \mathrm{~g})$ in horse meat, whereas Hertrampf (8) and Lorenzo et al. (23) estimated the phosphorus content of horse meat at $139 \mathrm{mg} / 100 \mathrm{~g}$ and $168-231 \mathrm{mg} / 100 \mathrm{~g}$, respectively. In the literature, differences are also reported in the calcium and iron content of horse meat. Korzeniewski et al. (18) and Lorenzo et al.

(23) determined the average calcium concentrations in horse meat at $6.58 \mathrm{mg} / 100 \mathrm{~g}$ and $3.77-8.65 \mathrm{mg} / 100 \mathrm{~g}$, respectively, and observed variations between individuals. The iron content of horse meat was estimated at 2.10 to $4.04 \mathrm{mg} / 100 \mathrm{~g}$ by Lorenzo et al. (23) and at $2.27 \mathrm{mg} / 100 \mathrm{~g}$ by Lombardi-Boccia et al. (22).

In human nutrition, meat largely fulfills the daily demand for B-group vitamins (1). Research has demonstrated (Tab. 2) that horse meat is a rich source of vitamins B3 (niacin), B6 (pyridoxine) and B12 (cobalamin) (2) and A (retinol) (20). According to Korzeniowski et al. (16), vitamin A concentrations can be several-fold higher in intensely colored horse fat than in beef tallow.

\section{Culinary uses and processing suitability of horse meat}

Because of its high content of collagen and glycogen, horse meat has to be aged before consumption. The aging process should be carried out under chilled conditions for at least 5 days to enhance its processing suitability and culinary uses (38-40).

Horse meat has a long shelf life due to specific transformations that take place in horse muscles post mortem (29). According to Znamirowska et al. (38), glycogenolysis is much slower in horses than in other animals, and the highest lactic acid concentrations in horse meat are noted three days after slaughter. The $\mathrm{pH}$ of meat remains low, which creates supportive conditions for biochemical transformations during aging $(30,38,40,42)$.

The high collagen content of muscle fibers contributes to the undesirable stringiness of horse meat, which 
cannot be eliminated by thermal processing. Research has demonstrated that the meat of cold-blooded horses was characterized by greater hardness, manifested in higher shear force values, than the meat of part-bred horses $(38,40)$.

Color is an important criterion by which consumers evaluate meat quality. In terms of color intensity, horse meat is insignificantly darker than beef from adult cattle. Horse meat is dark red with a tinge of brown due to the high content of myoglobin in muscle tissue. According to Znamirowska et al. (38), myoglobin concentrations are determined by various intravital factors, and they are not always associated with age. Myoglobin readily binds $\mathrm{O}_{2}$ and is converted into bright red oxymyoglobin, which, in turn, is oxidized to brown-grey metmyoglobin (24). Red color stability in fresh and stored horse meat is, therefore, limited (22).

Zin et al. (36) observed that meat with a desirable lighter color is obtained from carcasses with a lower lean meat content. Znamirowska and Zin (40) also found that the meat of cob horses is lighter in color because of higher marbling.

Marbling is an important quality attribute of meat, which significantly influences consumer acceptance. Horse meat is composed of thin muscle fibers intertwined with meltable fat with soft consistency and creamy color. Desirable marbling is noted only in the meat of horses with high body condition scores. The highest marbling was observed in cob and cold-blooded horses, which are characterized by the highest levels of body fat (36-38, 40, 41).

Raw and processed horse meat has a long storage life, which contributes to its processing suitability. Research has demonstrated that raw and processed horse meat retains its quality attributes after refrigeration and freezing $(13-15,29)$. In a study by Znamirowska et al. (42), raw meat freeze-stored for 30 or 90 days was characterized by improved sensory properties and resembled fresh meat that had been aged under chilled conditions for 120 days.

Horse meat can be cooked and consumed directly or converted into processed consumables, including smoked meats and sausages, with the application of appropriate processing technologies and recipes (25). The sensory attributes of processed horse meat products can be improved by modifying the aging process and applying selected pre-treatments, such as pickling in sour marinades, herbs, and spices. In a recipe suggested by Barowicz and Tatarczuch (3), horse meat is frozen for a short period of time, after which it is larded and rubbed with spices. The cited authors developed 125 recipes for horse meat, including starters, soups, main courses of cooked, roasted and braised meat, offal, and pâtés.

Cured meats have a high share of the meat market (34). Processing principles and requirements for horse meat and other types of meat are generally identical $(3,38)$. Processed horse meat products contain small amounts of pork and pork fat, as well as spices that are added to pork, beef, veal and mutton, but are used in much greater quantities in horse meat. According to Tereszkiewicz et al. (31), the most popular smoked product is smoked horse sirloin. Horse sirloin has a medium shelf life, it is hot-smoked in one piece, and the yield from raw meat is high at $86 \%$.

Another popular processed horse meat product is Belgian sausage, which belongs to the category of dry processed meats with a long shelf life. Belgian sausage is dark brown in color, and it is made of coarsely

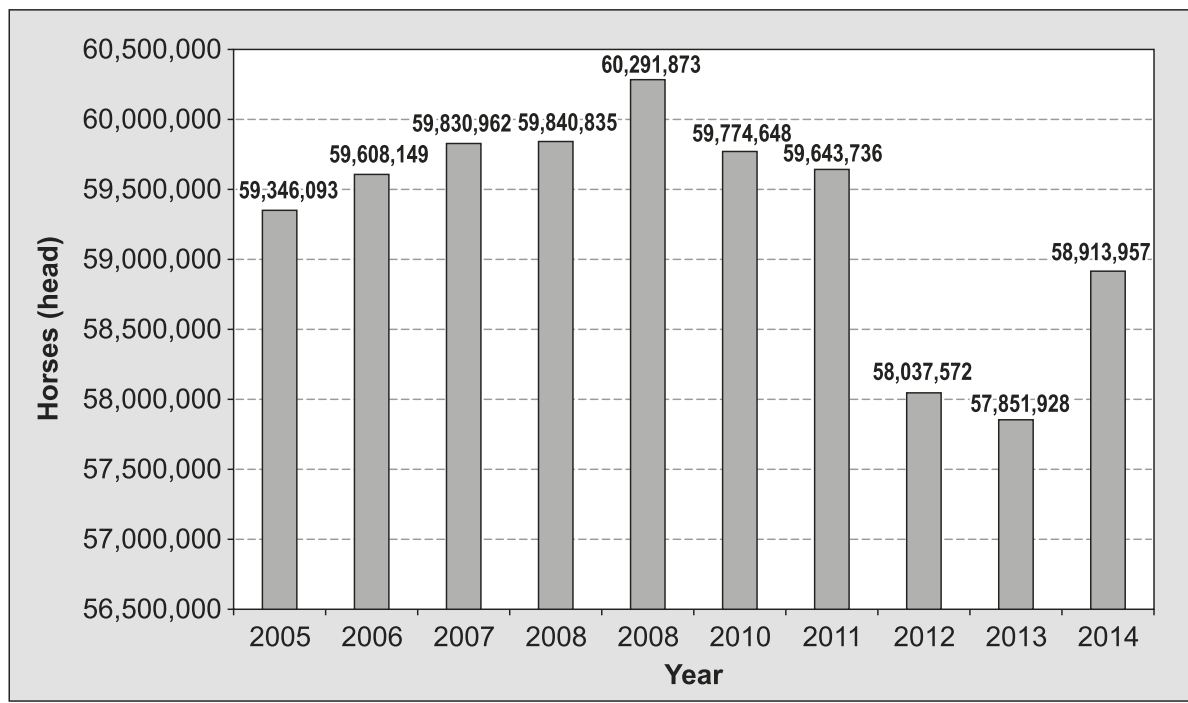

Fig. 1. Horse population in the world (FAO 2016)

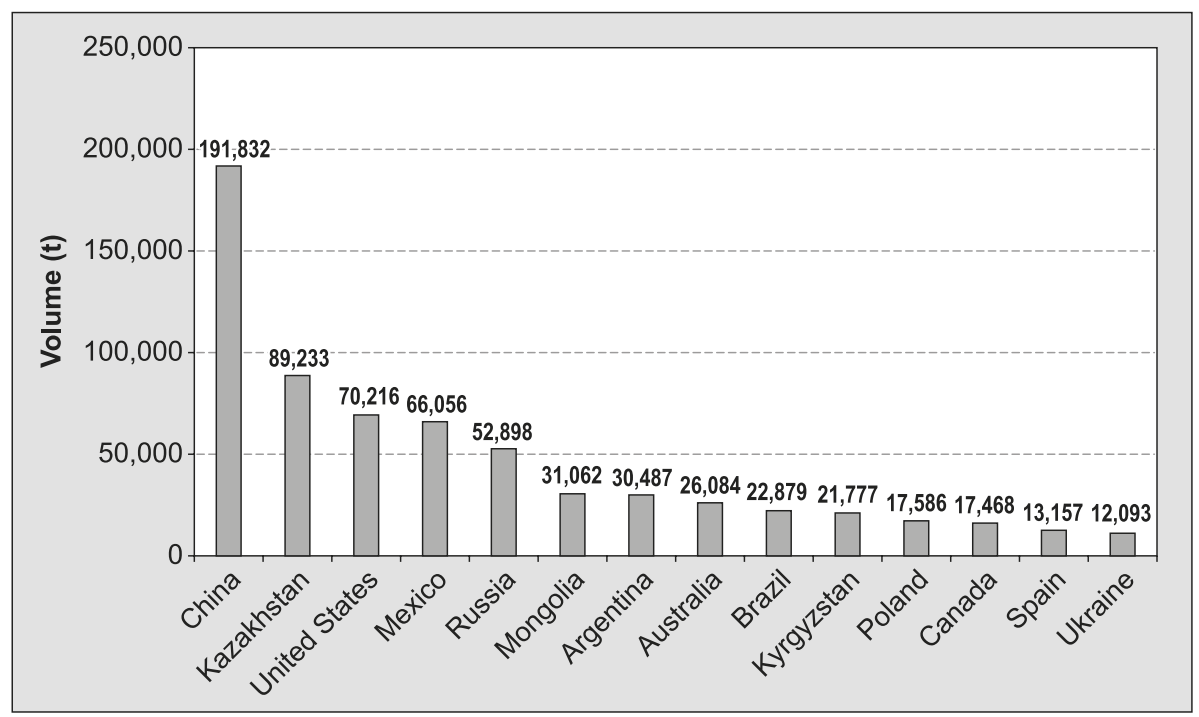

Fig. 2. The world's leading producers of horse meat in 2013 (FAO 2016) 
ground horse meat with discernible fat cubes. Horse meat is ideal for the production of uncooked smoked sausage such as salami. Authentic salami is made exclusively of horse meat with the addition of pork fat. It is considered a delicacy, in particular in northern Italy (3).

Horse meat is also processed into long thin dry sausage, known as kabanos in Poland. Kabanos sausage contains $80 \%$ horse meat, $10 \%$ pork, and $10 \%$ pork fat (3).

\section{Global market of slaughter horses and horse meat}

The horse meat industry is a niche market (23), with only $0.4 \%$ share of the global meat market and an average consumption of around $0.1 \mathrm{~kg}$ per capita (4). In 2014, the global horse population reached nearly 59 million, marking an increase from 2012 and 2013 and a decrease from 2005-2011 (Fig. 1). In 2014, the largest horse populations were noted in the United States $(10,260,000)$, Mexico $(6,355,000)$, China $(6,029,780)$, Brazil $(5,450,601)$, and Argentina $(3,600,000)$. A minor downward trend has been observed world-wide since 2005, excluding the United States (http://faostat.fao. org).

The European horse population exceeds 5.5 million (http:// faostat.fao.org). Kazakhstan boasts the largest horse population (nearly 1.8 million, $7^{\text {th }}$ largest in the world), but since $88 \%$ of Kazakh territory lies in Asia, Russia is the formal European leader, with a horse population of more than 1.3 million. Russia is followed by Romania (more than 500,000 horses), France $(410,000)$, Ukraine $(354,200)$, and Spain $(250,000)$, which are also large producers of horse meat (http://faostat.fao.org).

China is the world's largest supplier of horse meat, with an output of 191,800 tons in 2013 (Fig. 2). It is followed by Kazakhstan, which produced 89,200 tons of horse meat in 2013. Many Kazakhs continue to lead a nomadic lifestyle, and horse meat is a staple food in the traditional Kazakh diet. Between 1961 and 2010, Kazakhstan was not listed by FAO as an exporter of horse meat. Kazakhstan imports horse meat, and it bought 5,000 tons on foreign markets in 2013 (Fig. 3).
The third largest producer of horse meat is the United States (70,200 tons). In view of its large horse population, the production of horse meat in the United States could be expected to reach the levels noted in China. However, the American people have a strong emotional attachment to horses, and the slaughter of horses for human consumption is banned in the United States (http://faostat.fao.org, 19).

Mexico is the world's fourth largest producer of horse meat, with an output of 66,000 tons in 2013 . Mexico is the most stable supplier of horse meat, and it has ranked in the top three or top four producing countries since the 1960s.

Horse meat has unique properties, and it is produced for a relatively narrow group of consumers in countries which have traditions of eating horse meat. The top two importers of horse meat (Fig. 3) bought 20,000 tons in 2013. The largest importer of horse meat is Italy, which bought 24,700 tons in 2013. Italy is followed by Belgium, Russia, France, and the Netherlands. With the exception of Russia, those countries have long-standing traditions of eating and processing horse meat, and they have been the leading import-

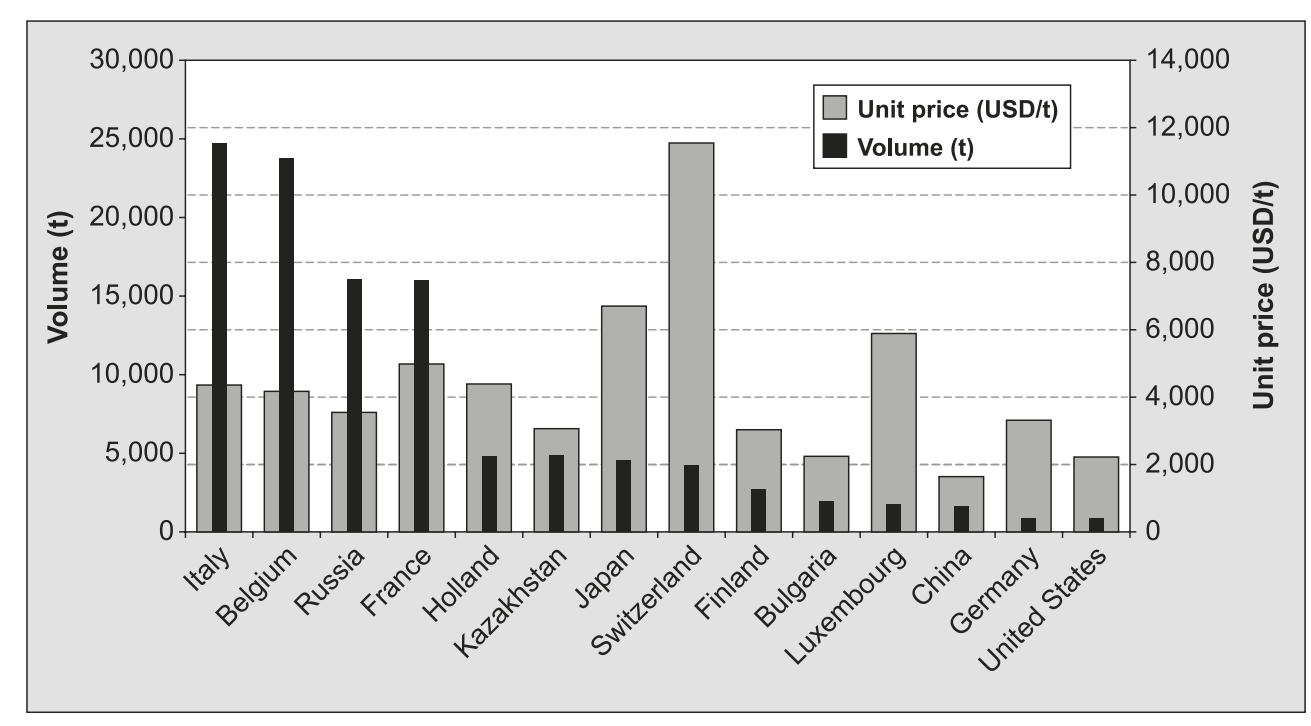

Fig. 3. The world's leading importers of horse meat in 2013 (FAO 2016)

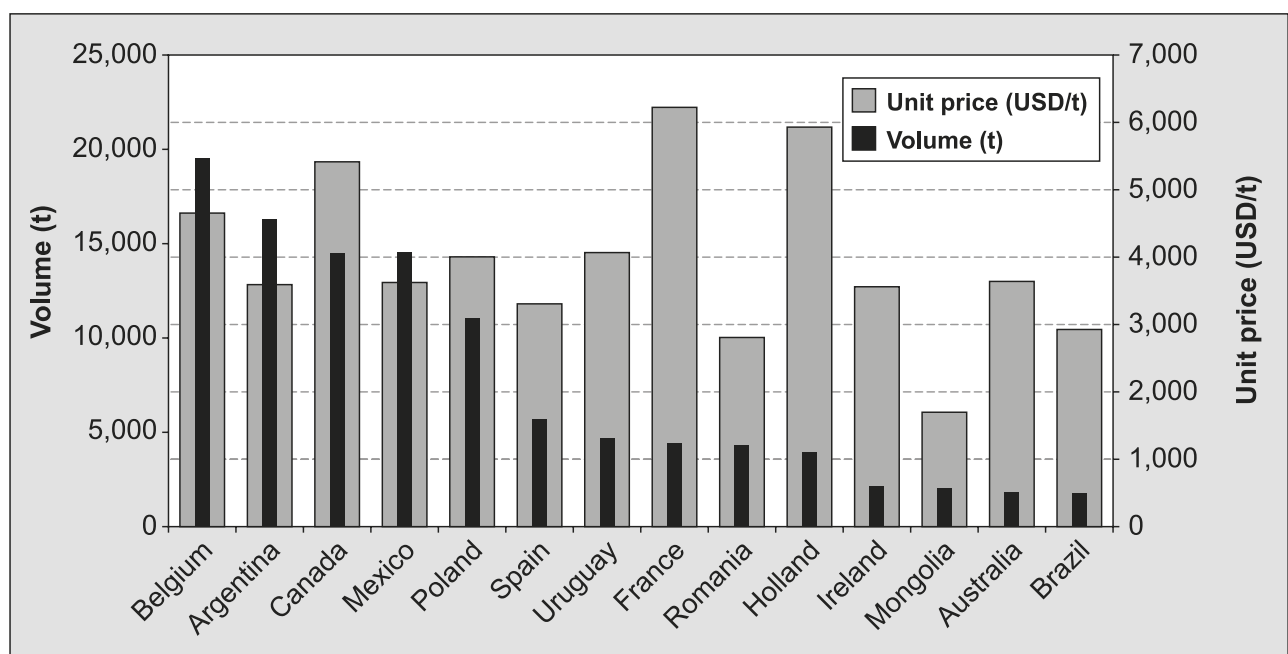

Fig. 4. The world's leading exporters of horse meat in 2013 (FAO 2016) 
ers of horse meat since at least 1961. Horse meat is considered a delicacy in those countries, and it fetches high prices. In 2013, the value of horse meat imports reached USD 107 million in Italy, USD 79 million in France, and USD 98 million in Belgium. The highest prices were quoted in Switzerland, which imported only 4,000 tons of horse meat in $2013\left(8^{\text {th }}\right.$ place in the world), but at the cost of more than USD 48 million (USD 11,526 per ton).

Horse meat is exported by countries where it is regarded on par with other types of meat, as well as by countries that do not eat horse meat and export most of their output (Fig. 4). The latter group of countries includes Argentina, which exported 16,300 tons of horse meat ( $54 \%$ of domestic output), and Canada, which sold more than 14,000 tons ( $51 \%$ of domestic output) in 2013. Belgium is also one of the leading exporters (nearly 20,000 tons in 2013), but unlike Argentina and Canada, it is also a large consumer of horse meat. Mexico and Poland export more than 10,000 tons of horse meat annually.

\section{Polish market of slaughter horses and horse meat}

In 2013, the Polish Horse Breeders Association (PZHK) estimated the Polish horse population at 310,600 (27), whereas Statistics Poland (GUS) (http://www.stat. gov.pl) quoted a lower number of 207,100, which gives Poland the $8^{\text {th }}$ place in Europe (excluding Kazakhstan) (http://faostat.fao.org). The Polish horse population was relatively stable in 2005-2008, and a steady decrease has been observed since 2009 (Fig. 5). Poland has been importing horse meat since 2003, mainly from Slovakia, Romania, Belarus, and Ukraine.

Poland has been a leading exporter of horses and horse meat in the European Union (EU) for many years, and it presents significant competition to North American exporters. In 2013, Poland exported more than 11,000 tons of horse meat (Fig. 4) worth more than USD 44 million (http://faostat.fao. org). Horse meat is rarely consumed in Poland, and 80$-95 \%$ of domestic output is exported. Poland's main trade partner is Italy, where the meat of cold-blooded horses is highly prized, followed by France, Belgium, Austria, and Germany, which buy $70-72 \%$ of Polish horse meat. Horse meat is also highly esteemed in Japan, which imports mostly deep-frozen and larded horse meat in vacuum packaging (33).

The steady decrease in Polish livestock exports since the 1990s has been compensated by an increase in horse meat exports. Poland sells half-carcasses in the form of pistol, flank, and forequarter cuts from which less valuable carcass elements have been removed. Fresh and frozen deboned meat accounts for $50 \%$ of Polish exports (http://faostat.fao.org, http://www.stat. gov.pl, 33).

The production of horse meat in the EU caters to only $50 \%$ of demand on the internal market, and Poland could become a competitive exporter because of the absence of import bans (33). Polish horses and horse meat account for approximately $60 \%$ of imports into the EU. These data indicate that Poland enjoys a strong and stable position on the list of horse meat exporters. The steadily growing demand for horse meat creates a positive outlook for Polish exporters.

The volume of Polish horse meat exports was stable in 2001-2010, with a minor upward trend (Fig. 6). A minor decrease has been noted since 2011. The value of Polish exports exceeded USD 40 million in 2007 and has remained fairly stable. In the analyzed years,

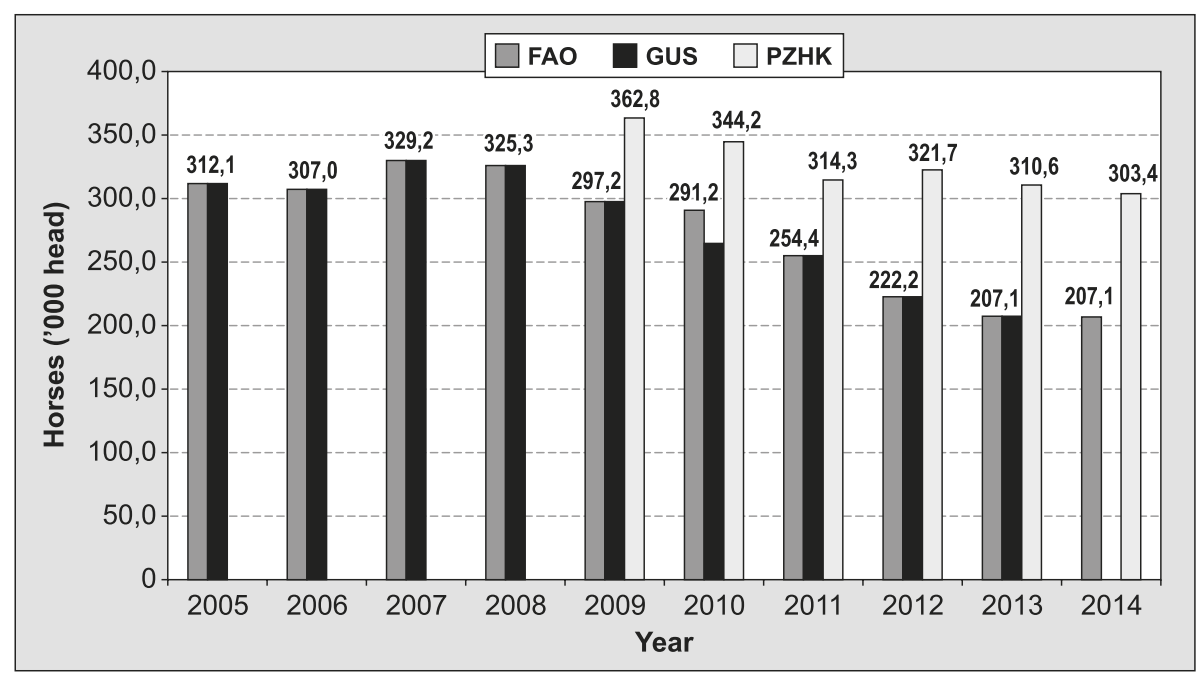

Fig. 5. Horse population in Poland (FAO 2016, GUS 2016, PZHK 2016)

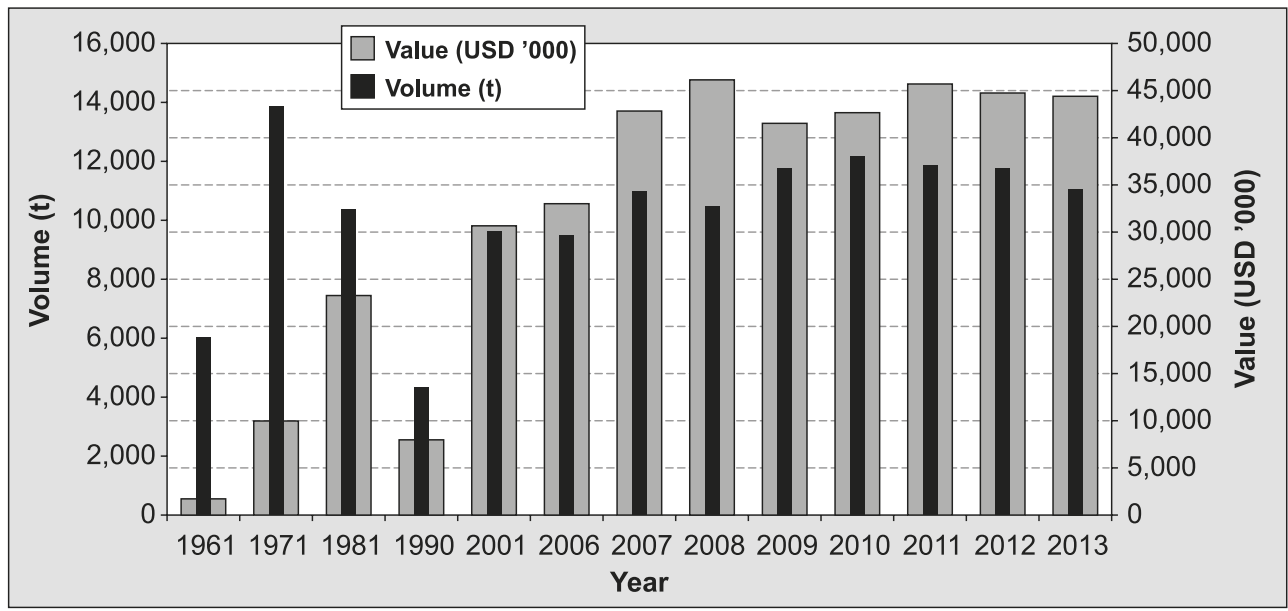

Fig. 6. Polish horse meat exports in the analyzed years (FAO 2016) 
Poland reported a highly positive balance of trade in horse meat, and the exported products fetched much higher prices than other types of meat and livestock species.

Poland does not export processed horse meat products, which are considered a delicacy in many Western European countries, where their luxury status is reflected in high prices.

\section{Analysis of the Polish market of slaughter horses and horse meat}

GUS (http://www.stat.gov.pl) and the Polish Horse Breeders Association - (27) differ in their estimates regarding the number of horses slaughtered for human consumption in Poland (Fig. 7). Similarly to the

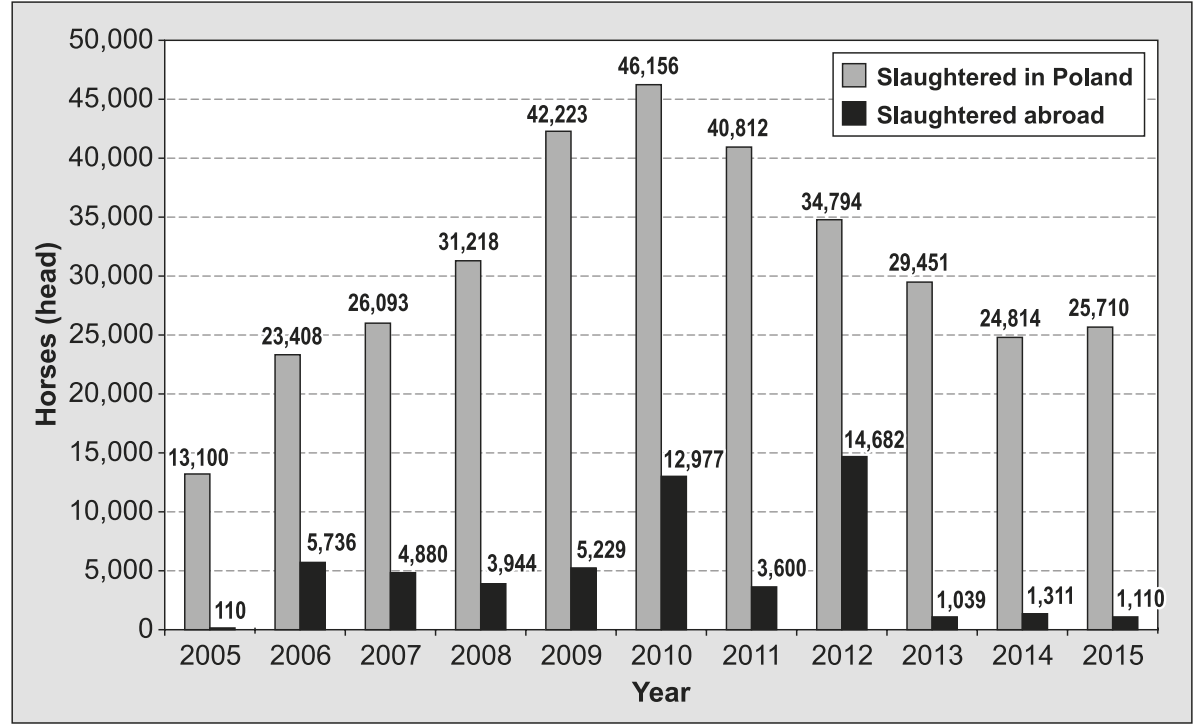

Fig. 7. Number of slaughtered horses bred in Poland (PZHK 2016) estimates regarding the Polish horse population, the data provided by GUS seem to be underestimated. The Polish Horse Breeders Association is an organization that deals specifically with horse breeding, and it is likely to be a more reliable source of data. The information provided by the Polish Horse Breeders Association is based on horse passports, obligatory documents that allow horses to be accurately identified. The number of horses slaughtered in Poland fluctuated in 2005-2013. An upward trend had been observed until 2010, when the number of slaughtered horses exceeded 45,000. The number of slaughtered horses clearly decreased between 2011 and 2014, and this trend was reversed only in 2015. The number of horses exported live and slaughtered outside Poland decreased significantly from 4,000-5,000 per year in 2006-2009 to over 1,000 in 2013-2015. The record-breaking years in this respect were 2010 and 2012, when 12,900 and 14,600 horses were exported, respectively. Between 2005 and 2015, a total of 337,779 horses were slaughtered in Poland, and 54,618 animals were exported live. It should be noted that statistical data account for horses that had been exported for slaughter, but feedback information from a foreign slaughter plant was never received (http://www.stat.gov.pl, 27).

The percentage of horse breeds that are exported live is similar to the percentage of horse breeds that are slaughtered in Poland. The majority of slaughtered horses are cold-bloods. More than 140,000 of coldblooded horses were slaughtered in 2011-2015. By comparison, 27,200 Polish half-bred horses and more than 9,000 miniature horses and ponies were slaughtered in the same period (27).

Statistical data indicate that the horse meat industry will continue to occupy a market niche in the nearest future. The low popularity of horse meat can be associated with the emotional aspects of horse-human interactions that have evolved throughout the centuries, in consequence of which, horses are regarded

as companion animals rather than a source of food. Campaigns promoting the attractiveness and high nutritional value of horse meat are unlikely to change those attitudes. The demand for horse meat will be maintained at a high level in countries where horse meat is traditionally eaten without creating social controversy (Mongolia, Kazakhstan, Kyrgyzstan, Iceland, Switzerland, Italy, Croatia, Belgium, Russia, Finland, France, Malta, Ukraine, and Greece). The demand on Western European markets is not fully met, which creates new opportunities for traditional exporters of horse meat. It should be noted, however, that Western European markets are highly demanding and competitive, so that only suppliers of top-quality products can hope to secure a lasting foothold in those markets.

\section{References}

1. Allman-Farinelli M.: Meat and poultry, [in:] Mann J., Truswell A. S. (eds): Essentials of Human Nutrition. Oxford University Press, Oxford 2007, p. 365-376.

2. Badiani A., Nanni N., Gatta P. P., Tolomelli B., Manfredini M.: Nutrient Profile of Horsemeat. J. Food Compos. Anal. 1997, 10, 254-269.

3. Barowicz T., Tatarczuch W.: Konina na naszym stole. Wyd. Watra, Warszawa 1988.

4.Belaunzaran X., Bessa R. J. B., Lavín P., Mantecón A. R., Kramer J. K. G., Aldai $N$.: Horse-meat for human consumption - Current research and future opportunities. Meat Sci. 2015, 108, 74-81.

5. Bo C. del, Simonetti P., Gardana C., Riso P., Lucchini G., Ciappellano S.: Horsemeat consumption affects iron status, lipid profile and fatty acid composition of red blood cells in healthy volunteers. Int. J. Food Sci. Nutr. 2013, 64, 147-154.

6. Dobranić V., Njari B., Mioković B., Cvrtila Fleck Ž., Kadivc M.: Chemical composition of horse meat. Meso 2009, 11, 62-67.

7. Franco D., Lorenzo J. M.: Effect of muscle and intensity of finishing diet on meat quality of foals slaughtered at 15 months. Meat Sci. 2014, 96, 327-334. 8. Hertrampf J. W.: Mythos Pferdefleisch. Fleischwirtschaft. 2003, 01, 88-92.

9. Hintz H. F.: Thoughts about the history of horses. J. Equine Vet. Sci. 1995, $15,336-339$

10. Hyyppä S., Räsänen L. A., Pösö A. R.: Resynthesis of glycogen in skeletal muscle from Standardbred trotters after repeated bouts of exercise. Am. J. Vet. Res. 1997, 58, 162-166.

11. Immonen K., Kauffman R. G., Schaefer D. M., Poulanne E.: Glycogen concentrations in bovine longissimus dorsi muscle. Meat Sci. 2000, 54, 163-167.

12. Kiple K. F., Ornelas K. C. (eds): The Cambridge World History of Food. Vol. 1. Cambridge University Press, Cambridge, UK, 2000, p. 543. 
13. Kondratowicz $J$.: Effect of natural fat addition on changes in the weight and sensory quality of horsemeat frozen according to different methods. Natur. Sc. 2001, 8, 183-192.

14. Kondratowicz $J$.: Wpływ różnych metod mrożenia na zmiany składu podstawowego i wybranych właściwości fizykochemicznych mięsa końskiego w czasie 6-miesięcznego przechowywania chłodniczego. Rocz. Inst. Przem. Mięs. Tłuszcz. 2001, 38, 61-69.

15. Kondratowicz J., Sobina I.: Effect of enrichment and different methods of the freezing on the chemical composition and physico-chemical properties of horsemeat. Natur. Sc. 1999, 2, 211-218.

16. Korzeniowski W., Jankowska B., Kwiatkowska A.: Zawartość karotenu i witaminy A w thuszczach końskich. Med. Weter. 1993, 49, 419-421.

17. Korzeniowski W., Kwiatkowska A., Jankowska B.: Jakość końskiej tkanki mięśniowej i thuszczowej. Med. Weter. 1994, 50, 486-488.

18. Korzeniowski W., Kwiatkowska A., Jankowska B.: Warto polubić koninę. Przeg. Gastronom. 1999, 8, 8-9.

19. Laurence R.: Cowboys and vegetarians: The proposed "American Horse Slaughter Prevention Act”. Arkansas Law Notes 2003, p. 103-107.

20. Lee C.-E., Seong P.-N., Oh W.-Y., Ko M.-S., Kim K.-I., Jeong J.-H.: Nutritional characteristics of horsemeat in comparison with those of beef and pork. Nutr. Res. Pract. 2007, 1, 70-73.

21. Levine M. A.: Eating horses: the evolutionary significance of hippophagy. Antiquity. 1998, 72, 90-100.

22. Lombardi-Boccia G., Lanzi S., Aguzzi A.: Aspects of meat quality: trace elements and B vitamins in raw and cooked meats. J. Food Compos. Analysis. 2005, 18, 39-46.

23. Lorenzo J. M., Sarriés M. V., Tateo A., Polidori P., Franco D., Lanza M. Carcass characteristics, meat quality and nutritional value of horsemeat A review. Meat Sci. 2014, 96, 1478-1488.

24. Mancini R. A., Hunt M. C.: Current research in meat color. Meat Sci. 2005 , $71,100-121$

25. Paleari M. A., Moretti V.M., Beretta G., Mentasti T., Bersani C.: Cured products from different animal species. Meat Sci. 2003, 63, 485-489.

26. Poławska E., Cooper R. G., Jóźwik A., Pomianowski J.: Meat from alternative species - nutritive and dietetic value, and its benefit for human health - a review. CYTA-J. Food. 2013, 11, 37-42.

27. Polish Horse Breeders Association (Polski Związek Hodowców Koni). Sprawozdanie z działalności Polskiego Związku Hodowców Koni w latach 2008-2011. XXVII Walny Zjazd Delegatów Polskiego Związku Hodowców Koni, Warszawa 27 maja 2012.

28. Rosenvold K., Laerke H. N., Jensen S. K., Karlsson A. H., Lundström K., Andersen $H$. J.: Strategic finishing feeding as a tool in the control of pork quality. Meat Sci. 2001, 59, 397-406.
29. Rudy M., Zin J., Głodek E.: Wpływ składu modyfikowanej atmosfery na trwałość mięsa i wędlin podczas chłodniczego przechowywania. Ann. Univ. Mariae Curie-Skłodowska EE 2007, 25, 79-84.

30. Stanisławczyk R.: Przebieg zmian glikolitycznych w mięsie końskim po chłodniczym i zamrażalniczym przechowywaniu w zależności od wieku zwierząt. Żywność. Nauka. Technologia. Jakość 2012, 85, 118-126.

31. Tereszkiewicz K., Molenda P., Pokrywka K., Bukała B.: Transport koni rzeźnych. Logistyka 2014, 3, 6315-6325.

32. Tonial I. B., Aguiar A. C., Oliveira C. C., Bonnafé E. G., Visentainer J. V., de Souza N. E.: Fatty acid and cholesterol content, chemical composition and sensory evaluation of horsemeat. S. Afr. J. Anim. Sci. 2009, 39, 328-332.

33. Urban S.: Udział Polski w międzynarodowym handlu koniną. Gosp. Mięsna 2008, 60, 20-22.

34. Wyness L., Weichselbaum E., O'Connor A., Williams E. B., Benelam B., Riley H., Stanner S.: Red meat in the diet: an update. Nutrition Bull. 2011, 36, 34-77.

35. Zin M., Szmulik A., Budzyński M.: Korelacje zachodzące pomiędzy cechami wartości rzeźnej koni. Ann. Univ. Mariae Curie-Skłodowska EE 1999, 17, 221-231.

36. Zin M., Znamirowska A., Budzyński M.: Wpływ umięśnienia tusz końskich na skład tkankowy i jakość fizykochemiczną mięsa. Ann. Univ. Mariae CurieSkłodowska EE 2000, 18, 165-173.

37. Znamirowska A., Budzyński M., Zin M.: Analiza wartości rzeźnej koni polskich i pochodzenia rumuńskiego. Ann. Univ. Mariae Curie-Skłodowska EE 2003, 21, 359-368.

38. Znamirowska A., Budzyński M., Zin M.: Analiza wartości użytkowej mięsa koni polskich i pochodzenia rumuńskiego. Ann. Univ. Mariae Curie Skłodowska EE 2003, 21, 369-377.

39. Znamirowska A., Stanisławczyk R.: Effect of maturing process on changes in physico-chemical properties of colt meat. Acta Sci. Pol. Technol. Aliment. 2005, 4, 79-88.

40. Znamirowska A., Zin M.: Ocena mięsa uzyskanego od koni o różnym typie pochodzeniowo-rasowym. Rocz. Inst. Przem. Mięs. Tłuszcz. 2003, 40, 53-59.

41. Znamirowska A., Zin M., Budzyński M.: Wpływ otłuszczenia półtusz końskich na jakość mięsa. Ann. Univ. Mariae Curie-Skłodowska EE 2000, 18, 155-164.

42.Znamirowska A., Zin M., Budzyński M.: Wpływ warunków przechowywania na jakość sensoryczną koniny. Ann. Univ. Mariae Curie-Skłodowska EE 2006, 40, 297-306.

Corresponding author: Ewa Jastrzębska, Eng. PhD, Prawocheńskiego 2, 10-719 Olsztyn; e-mail: e.jastrzebska@uwm.edu.pl 